\title{
SCIDOC
}

International Journal of Finance, Economics and Trade (IJFET) ISSN 2643-038X

\section{Blockchain-Based Innovation in Post-COVID-19 Trade Finance}

Ricardo Henríquez ${ }^{1 *}$, F. Xavier Martínez de Osés ${ }^{1}$, Jesús E. Martínez Marín², Cristina Tomás ${ }^{3}$

${ }^{1}$ Catalonia Polytechnic University, Department of Nautical Sciences and Engineering, Pla del Palau 18, 08003 Barcelona, Spain.

${ }^{2}$ Pompeu Fabra University, Technocampus. Carrer d'Ernest Lluch, 32, 08302 Mataró, Spain.

${ }^{3}$ EAE Business School, Carrer de Aragó 55, 08015 Barcelona, Spain.

\section{Abstract}

While trade finance has been recognized as a key enabler in international trade, there is a persistent gap between supply and demand. This gap threatens to widen after the shocks suffered during the COVID-19 pandemic, which increased risks perception and decreased credit appetite. As a parallel phenomenon, distributed ledger technology (DLT), aka blockchain, has given birth to the decentralised finance (DeFi) paradigm, promising to revolutionize banking and the whole financial sector. This paper enquires whether a DeFi-based business model could address the trade finance gap problematic under the context and challenges created by the COVID-19 pandemic, particularly in relation to SMEs located in developing and least developed countries. To this end, it designs and presents a DeFi trade finance business model, showing how it could address the reasons behind the trade finance gap, while developing at the same time a broader meaning of the DeFi concept itself.

Keywords: Trade Finance Gap; Letter Of Credit; DeFi; Blockchain; Business Model Innovation; Alternative Finance.

\section{Introduction}

Trade finance - and in particular its traditional instrument, the letter of credit (LC) - aims to protect exporters and importers alike from the risk of non-completion. Without an LC, many international trade transactions would be too risky to undertake. Lack of access to trade finance, therefore, translates into lost trade opportunities [4].

The importance of trade finance for international trade and economic development has gained increased attention in the last few years. International organizations have observed once and again the persistence of a huge gap between supply and demand of trade finance - currently estimated at US\$ 1.5 trillion- $(1,77)$ with negative consequences for trade, most particularly for small and medium enterprises (SMEs), and for emerging and frontier economies [3]. The crisis generated by the COVID- 19 pandemic, which significantly disrupted supply chains, only made things worse, and new estimations project a trade finance gap of US $\$ 2.5$ trillion by 2025 [11].
Causes behind this huge gap are various and complex. However, the main reasons usually mentioned by practitioners are the negative impact of regulations, insufficient liquidity in local banks, high transaction costs/low profitability, and lack of trust issues (e.g. LC applicant insufficient creditworthiness, low country reputation, difficult contract enforcement, etc.) [43]. Among the proposed answers to this problem are changes in banking regulations and compliance (making them risk based), and expansion of credit supply through multilateral banks and export credit agencies (ECA) [44].

In parallel, during the last decade, there has been considerable technological developments in the financial industry, with a surge (and success) of so-called "fintech firms". Most particularly, in the last few years, blockchain-based decentralised finance (DeFi) has attracted attention as a non-conventional way of coping with financial needs.

Against this background it is thus valid to ask whether DeFi could provide an alternative solution (or at least be part of it) for the

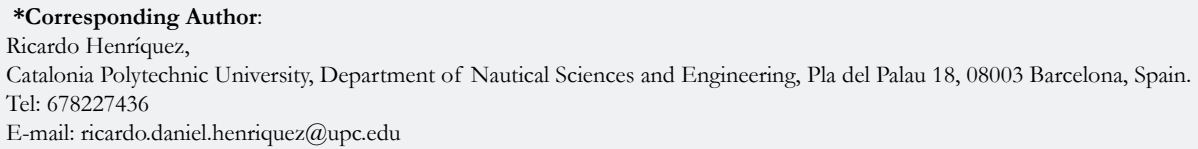

Copyright: Ricardo Henríquez ${ }^{\circ} 2021$. This is an open-access article distributed under the terms of the Creative Commons Attribution License, which permits unrestricted use, distribution and reproduction in any medium, provided the original author and source are credited. 
trade finance gap [74, 75]; and if so, how could such a solution be designed and implemented. This research study aims to answer this question by presenting an innovative, DeFi-based business model for trade finance.

Section 2 presents the theoretical background on the trade finance problematic, with particular mention of the context created by the COVID-19, as well as on the topic of financial intermediation and business model innovation. Section 3 explains the research methodology. Section 4 discusses decentralised finance, offering a new conceptual approach. Section 5 describes the business model for a decentralised, blockchain-based trade finance system. Section 6 makes an ex-ante, preliminary evaluation of the model. Finally, Section 7 presents conclusions, limitations and suggestions for future research.

\section{Theoretical Background}

The trade finance gap problem and its potential answer in the form of DeFi can be approached from diverse theoretical perspectives: management science, legal studies, micro and macroeconomy, etc. This reflects its complex nature, with causes and consequences spanning several areas. In this section, we shall begin by referring to the reasons behind the gap, as exposed in policy discussions, including the post-COVID-19 context.

Afterwards, the problematic and its likely solution will be analysed against the conceptual background provided by the theories of financial intermediation and of business model innovation. In the process, we shall also approach the concept of decentralised finance $(\mathrm{DeFi})$ from a new perspective.

\section{Causes of the trade finance gap}

Several causes for the persisting trade finance gap have been observed in policy discussions. These causes may be divided into supply-related (affecting the capacity of banks or other financiers to provide capital for transactions) or demand-related (referred to the importing and exporting firms that transact with each other). Table 1 classifies the causes along this division criteria. In some cases, however, the same cause can be considered both as supply and demand related. Each cause is treated under the light of policy discussions and academic literature.

\section{Supply-related causes}

In the wake of the $2008 / 9$ financial crisis, and its negative repercussions in the following years (e.g.: the sovereign debt crisis in some European countries), financial regulations were stiffened $[32,73]$. Among several areas covered by new banking regulations, two main ones stand: capital requirements and due-diligence procedures.

The Dodd-Frank Act in US, the Regulation (EU) No 575/2013 in the EU, and the Third Basel Accord (Basel III) on a global stage, increased the capital requirements for banks. These measures, aimed at lowering excessive risk taking by financial institutions in the previous years, had the negative effect of lowering profitability and decreasing liquidity for trade finance, as observed repeatedly in policy discussions $[3,43,44]$.

Consequences of capital requirements regulation on the level of financial supply, have been extensively studied in the financial literature, particularly in the context of discussions about the relationship between banks' liquidity and their risk taking [2, 19, 42, 45]. More recently, a couple of European Central Bank work papers analyse the short-term effects of capital requirements on credit supply: [53] observe that, in the short run, rising capital requirements may have contractionary effects on credit supply and economic activity (what they name "transitional costs"), even if they generate positive effects in the long run by reducing systemic risk taking. Likewise, [17] find a material impact of capital requirements on the supply of loans, though the effect is moderated by bank's initial balance sheets, with banks that are closer to the minimum capital requirements been more likely to reduce lending. These constraining effects of higher capital requirements and limited bank liquidity have also been pointed out in the specific case of trade finance $[4,10,12]$. Due-diligence regulatory requirements, particularly those related to "Know your customer" (KYC) and anti-money laundering (AML) have also been correlated with constraining credit supply, based on results from banks' surveys $[13,43,44]$. A necessary balancing between financial integrity and financial inclusion, with a risk-based approach to KYC and AML has thus been proposed [35, 43, 44].

Other supply-related causes for the trade finance gap have been mostly pointed out in policy reports $[1,3,43,44,77]$. These include an insufficient involvement of non-bank investors in the secondary market; high- processing costs, especially for document

Table 1. Classification of Trade Finance Gap Causes.

\begin{tabular}{|c|c|c|}
\hline Trade finance gap causes & Supply-related & Demand-related \\
\hline Increased capital ratio requirements in banking regulations & $\mathrm{X}$ & \\
\hline Regulatory due-diligence requirements & $\mathrm{X}$ & \\
\hline Minimal non-bank capital & $\mathrm{X}$ & \\
\hline High processing costs & $\mathrm{X}$ & $\mathrm{X}$ \\
\hline Document verification problems & $\mathrm{X}$ & $\mathrm{X}$ \\
\hline Insufficient knowledge about trade finance & $\mathrm{X}$ & $\mathrm{X}$ \\
\hline Firm related high level of risk & & $\mathrm{X}$ \\
\hline Country related high level of risk & & $\mathrm{X}$ \\
\hline Insufficient size of transactions & & $\mathrm{X}$ \\
\hline
\end{tabular}


verification, due to the still mostly paper-based nature of letters of credit; and insufficient knowledge about trade finance by local banks in emerging and frontier economies [31].

High processing costs are related to both supply-side and demand-side considerations for trade finance. For banks, higher processing costs mean lower profitability of trade finance instruments overall, which makes them to limit their credit supply in favour of other, less complex financial assets.

\section{Demand-related causes}

Demand-related causes for the trade finance gap are those that originate in the importing and exporting firms that require trade finance for their transactions. These can be taken as the answer to the following two, more specific questions: 1) what motivates the rejection of letter of credit applications? and 2) what limits importers/exports to seek trade finance in the first place? [13] observe three types of drivers for trade finance rejections: country-related, firm-related, and bank-related. The country-related reasons include high political and economic risk, underdeveloped finance system, and low contract enforceability. [56, 57] find that in countries with higher risk and lower contract enforceability, letters of credit are used more than documentary credits.

Bank-related rejections are those that take place among bank's themselves, more specifically, between the exporter's (confirming) bank and the importer's (issuing) bank. This aspect is closely related with country risks and is manifest in the ongoing decrease of correspondent bank relationships, as global banks move to lower risk economies $[11,13,43]$. This phenomenon, admittedly, is more related to the supply-side of trade finance, but it is grounded in the economic environment where the importing firm is located.

Firm-related reasons for trade finance rejection are mainly due to insufficient collateral and creditworthiness issues, reflecting information asymmetries issues that limit credit availability [68]. This affects predominantly small and medium enterprises (SME), for which is then increasingly difficult to join global supply chain networks.

Besides actual rejections, the demand-side of the trade finance gap is also affected by the high processing costs of instruments like letters of credits (LC), which include a fixed cost component for document handling and screening. The practical implication is that LCs become economically viable only for transactions that surpass certain size threshold [56]. This, again, primarily affects SMEs, which on average engage in lower size transactions than large corporations [57].

\section{Post-COVID-19 pandemic context}

From the very outset, the COVID-19 pandemic caused a serious disruption in supply chains and international trade. By the end of 2020 , the OECD estimated a $10.9 \%$ contraction in global trade [60]. Given the complexity, diversification and interconnectedness of global value chains, the unavailability of intermediate products had a domino-like effect, affecting the whole chain [72].

Apart from the general disruption of international trade, financial flows were severely affected [64], and trade finance in particular [60]. Both supply-related and demand-related sides were impact- ed. On the supply-side, there has been a generalized increase in risk perception and consequent decrease in credit appetite, with international banks "re-shoring" lending and focusing on "safer" customers [11]. On the demand-side, there has been an increase in applications to documentary credits, ECA guarantees and payment deferrals $[11,60]$; with evidence showing that trade flows backed by letters of credit or documentary collections showed no significant decline [30]. In addition, the lockdown created operational challenges that affected processes like the transmission of trade finance related documents [11]. This especially affected countries where digitalization is low, like most of Africa [58].

The reaction to these challenges, however, has been considerably more effective than in the case of the 2008 financial crisis. In particular, liquidity and credit provision from government entities, multi-lateral banks and ECAs has been crucial in propping up supply $[11,21,60]$.

Despite some recovery, the way ahead for trade finance looks arduous, as the above- mentioned decrease in supply and increase in demand are expected to persist. Key international suppliers like BNP Paribas, Société Générale and ABN-AMRO have restricted or closed whole trade finance segments, without any clear answer as to how this gap will be filled in the short term. Besides, specific challenges have surged, like the need to finance the transportation and international distribution of vaccines [11].

Among the measures proposed for the post-COVID era are more direct support from governments in the form of grants and loan guarantees, securitization of loans by central banks [22], further liquidity provision by ECAs [60], and promotion of non-traditional trade finance solutions like factoring and forfeiting in countries with significant gaps [11].

\section{Financial intermediation}

The traditional role of banks is to act as financial intermediaries, taking deposits from individuals (households) and channelling them to economic agents requiring capital (firms). This role of banks has been justified by a theory of financial intermediation based on transaction costs [18], asymmetry of information $[9,23]$, risk management and participation costs $[6,7]$.

This traditional role, however, has undergone important changes in the last three decades. First, as observed by [6], banks have concentrated in risk management activities, and the decrease for their clients of what the authors denominate "participation costs", i.e., the cost of 'learning how the market works, the distribution of asset returns and how to monitor changes through time' ( $p$. 1481). In other words, the main value adding function performed by banks have been not to act as financial buffers between depositors and borrowers, but as risk managers and financial know-how providers.

Technological changes have also significantly affected the role performed by banks. During the last two decades, with the surge of electronic marketplaces, a disintermediation process has taken place $[28,48,55,61]$. Some authors describe an intermediation/ disintermediation/ re intermediation cycle [26, 27] where some traditional intermediaries, after being disenfranchised as a consequence of technological innovations, find new ways to compete by leveraging these innovations. Financial disintermediation has 
been noticed in several fields, notably P2P lending [20, 24] and virtual currencies [62].

Following the "functional perspective" of the financial system $[6,54]$, these trends could be understood as a sort of financial intermediation reengineering. The same underlying functions are performed in different ways and by different players as technology and economic forces evolve, thus generating new business models.

\section{Business model innovation}

During the last decade, business model innovation has been defined and explained by different (and competing) paradigms and schools [34]. One of them, the Activity System school (aka IESE/Wharton school), defines a business model as a set of activities, resources and capabilities (held within the firm or across its boundaries), that allow a firm to create value and appropriate a share of it $[79,80]$. Therefore, a modification in the distribution of these activities, resources and capabilities aimed to generate and appropriate economic value, would traduce into business model innovation.

From a different perspective, the Recombination school (aka St. Gallen school) understands a business model as a "recombination of patters" for answering 4 key questions about a business: who is the customer? what is the supplied value? how is this value created and distributed? and why is the business profitable? [34]. One of the core tenets of this school is that most of business models are built out of repetitive patterns, whose recombination amounts to business model innovation (BMI) [33]. BMI should be, therefore, a problem-solving undertaking where a business uses existing knowledge and technologies to generate and distribute value in innovative ways.

Delving into the afore described theoretical background, this paper has two main research objectives. First, to discuss and understand the concept of decentralised finance under the framework provided by the concepts of financial intermediation and business model innovation. And second, to design a model for a decentralised finance system that could provide a solution, if only partial, to the trade finance gap problematic, taking into account the context created by the COVID-19 pandemic. These objectives will be dealt with in sections 4 and 5, respectively. Previously, however, the research methodology is discussed in the following section.

\section{Research Methodology}

\section{Research paradigm}

The present study follows the Design Science Research (DSR) paradigm, frequently used in the Information Systems discipline $[41,52]$. The goal of DSR is twofold: solving a practical problem and generating theory, both through the creation of an IT artifact [16].

The IT artifact itself can be a construct, model, method or instantiation, and its creation follows two general stages: design/ building and evaluation [41, 52]. Though traditional DSR suggests a sequenced procedure (first design/build, then evaluate), recent literature has questioned this structure as too rigid. It is observed that evaluation can be parallel and intermingled with the design stage $[16,71]$, as well as that several design/evaluation iterations should be performed as the artifact is developed.

DSR begins by identifying a problem to be solved: in this case, the trade finance gap. A potential answer to this problem (among many) is aimed at through the development of a model (a business model). The model is developed in line with the DeFi paradigm, closely related to distributed ledger technology (blockchain).

The second general stage of DSR is the evaluation of the proposed artifact. The evaluation needs to cover two aspects, which correspond to the twofold goal of DSR: whether the artifact is useful in addressing the perceived problem, and whether the creation of the artifact generates new knowledge.

A full evaluation of an artifact should include its instantiation, i.e., the functioning artifact operating in the real world. For the research here undertaken, a full evaluation would imply an assessment on whether an instantiation of the proposed model effectively addresses the reasons behind the trade finance gap. In other words, a full DSR evaluation would require for an actual artifact to be already in the market.

However, as literature on DSR has observed, the evaluation of the artifact is conducted through several iterations, which cover not only its final instantiation, but also its preliminary design/ blueprint in terms of models. In this sense, a distinction is made between ex-ante and ex-post evaluations $[67,71]$. Ex-ante evaluations are made over the artifact's model before it is instantiated. Given that the objective of this paper is to design and propose a new business model for trade finance, the assessment to be presented in Section 6 constitutes an ex-ante evaluation of the corresponding blueprint. It represents the first step in the DSR which should be completed when an actual instantiation of the model is developed and introduced in the market (as a new system, or even as a startup). At that final stage, an ex-post evaluation can be conducted.

\section{Business modelling}

As previously mentioned, the artifact to be presented in this paper is a model; more specifically, a business model. As expressed by [14], who follow the Cognitive School (aka Cass School), a business model is first and foremost a cognitive

representation of a particular way in which value is created, delivered and captured; and business modelling is a set of cognitive actions that aim to articulate that representation [15, 34]. As a representation, a business model then simplifies and abstracts the details of concrete, real-life businesses activities. It does so, however, with the intention of facilitating change, in the sense that it is easier and more efficient to manipulate a conceptual model than to blindly execute changes in business activities following a trial/error process. The conceptual changing processes proposed by the authors, and partially followed here, are expressed as 6 modular operators: splitting, substituting, augmenting, inverting, excluding and porting.

The modelling process to be followed has two basic stages. First, the traditional way of providing trade finance through an LC will 
be depicted. This depiction amounts to a general level representation of value creation, delivery and capture. Then, some of the modular operators proposed by [14] will be applied to the traditional model, in order to design a recombined way of creating, delivering and capturing value. As shall be seen, these operators correspond with the different uses of the DeFi concept, as defined in the following section.

\section{What is Decentralised Finance (DeFi)?}

\section{Past and current definitions}

The term "decentralised finance" has been used with differing meanings in academic and policy discussions. For instance, it was associated with the concept of fiscal decentralization or "fiscal federalism" $[59,76]$, as well as with the spatial decentralisation of financial markets and how this might influence flows of capital to SMEs [46]. In more recent years, however, the expression gained a more specific meaning in the context of the blockchain revolution. At the beginning, most of the uses of the expression, including its associated abbreviation (DeFi) were to be found in blockchain related websites like Cointelegraph, online publishing platforms like Medium, or initial coin offerings' (ICO) whitepapers; its use in academic papers being very scarce. This, however, changed in the last couple of years, where several academic papers have been providing definitions of $\operatorname{DeFi}[8,39,65,78]$. The common element in these definitions is to identify DeFi with blockchain-based financial services; some of them limiting DeFi to solutions built in the Ethereum blockchain platform. An exception is the definition provided by [25] whom, while acknowledging the close relationship between DeFi and blockchain technology, emphasise instead the disintermediation and decentralization aspects of the new finance solutions.

Without denying the clear relationship between what is referred as "DeFi" and blockchain technology-based systems, this study considers that definitions which tie-up the concept with the technology are too narrow. Instead, in the line of [25], in this section we discuss four alternative (but complementary) uses of the DeFi concept: DeFi as disintermediation, as decreased concentration, as unbundling, and as alternative finance.

\section{DeFi as Financial Disintermediation}

One of the virtues for which Bitcoin and blockchain have been hailed is that they would allow individuals to transact with each other without recurring to banks. Some of these discussions are ideologically dressed in anarchic or libertarian colours, where banks (especially central banks) are at the root of all evils in the economy and society $[40,66]$. In more concrete terms, it is observed that one of the virtues of Bitcoin and distributed ledger technology (DLT) is that it allows for considerably faster processing of payments, clearance and settlement: a $\mathrm{T}+15$ ' system instead of the annoying $\mathrm{T}+2$ or $\mathrm{T}+3$.

Besides payments, other financial functions traditionally performed by banks are being disintermediated (with or without the technological help of DLT): loans (P2P lending systems), and risk management (AI-powered credit scoring). In other words, some of the factors behind the justification for banking intermediation (asymmetries of information, transaction costs, risk management, participation costs) [6], are being coped with through technological and business model innovation. This allows for the performance of those functions by entities different than banks or in a purely P2P basis. The disintermediation element is present in $\mathrm{DeFi}$, understood in a more encompassing way than simply as blockchain-based financial services.

DeFi as financial disintermediation corresponds with the excluding modular operator.

\section{DeFi as decreased concentration in the financial system}

As mentioned above, the term decentralized finance has been used to refer to capital markets that are geographically less concentrated (Germany) than others (UK) [46]. This level of spatial concentration in finance has its institutional, monetary and infrastructure counterparts. A financial sector can be more or less institutionally concentrated. Trade finance, for instance, is very highly concentrated: according to the ICC (2018), 90\% of trade finance in the world, by transaction value, is provided by only 13 banks. Money creation is more or less concentrated between central banks and commercial banks (by virtue of fractional banking) in the monetary circuit [49]. Financial ledgers are controlled by banks and central banks: they are purportedly being democratised by Bitcoin, where the ledger is being controlled by peer-nodes (in reality, there is a big concentration among a few Chinese mining pools) [29, 49].

DeFi is therefore to be also understood as a process of decreasing spatial, institutional, monetary or infrastructure concentration. Bitcoin would be a good example of decreased concentration in the spatial (access to Bitcoin has mostly no geographic limits), institutional (digital exchanges trading it have swarmed everywhere), and infrastructure senses. It is far less clear whether, with a few mining pools driving the increase in supply, Bitcoin is an example of monetary de-concentration.

\section{DeFi as unbundling of financial functions}

According to the above-mentioned functional perspective, over long periods of time, financial functions have been more stable than financial institutions: 'Institutions have come and gone, evolved or changed, but functional needs persist while packaged differently and delivered in substantially different ways' [6]. Traditionally, banks have been the institutions that have performed these functions, as a one-stop place for most of financial services.

The Fintech revolution that has been taking place during the last decade [36], has brought the "unbundling" of financial services. This business phenomenon is closely related with the disintermediation of some of these functions, but it is not identical with it. Disintermediation refers to coping with problems related with financial functions (like transaction costs or asymmetries of information) without a bank or other intermediary. Unbundling refers to the provision of those functions by specialized players (fintech firms).

Rather than relying in a single a bank as the unique solution for their financial needs, individuals and firms are increasingly picking up different services (payments, micro- loans, mortgages, investment) from separate fintech companies or so-called "shadow" banks [47]. The unbundling of functions is thus another element 
in our broad DeFi concept, corresponding with the splitting modular operator.

\section{DeFi as alternative finance}

One of the most salient phenomena brought about by block chain technology, most particularly by the Ethereum platform smart contract-based ERC-20 digital tokens, is that of fundraising through "initial coin offerings", better known simply as ICOs [70]. During the second half of 2017 and until the middle of 2018, all kind of startup projects, claiming to develop the next block chain disruptive use case, tried to raise capital by selling so-called "utility" or "use" tokens, under a sort of pre-sale of services business model. However, by the second half of 2018 the amount of raised capital had substantially decreased, a trend that has continued to the present day.

Despite the overwhelming number of failed ICOs (many of them outright scams or Ponzi schemes), token-based alternative financing has been recognized as a potentially powerful tool that could lead to a new economic paradigm, from centralized platforms and business models to decentralised ones [69]. Apart from its current use in startup funding, token-based issuing events (now re-christened IEOs: "initial exchange offerings", or STOs "security token offerings"), might work as well as tools for deploying secondary markets for securities.

ICOs, IEOs and STOs can be understood as tools for alternative finance, defined as sources of financing different than traditional bank and market finance channels [5]. This characteristic of being capable to constitute an alternative source of financing is the last element in our DeFi conceptualization.

The alternative finance use corresponds with the substituting modular operator.

The former elements are meant as "badges" to identify instances of decentralised finance, and do not have to be all present for a financial system, method or tool to be considered as such. The purpose here is not to offer a complete and clear definition of DeFi; rather, it is to show several aspects where DeFi can be more effective and efficient than traditional finance in addressing the trade finance gap and in coping with financial needs, particularly those of SMEs in emerging and frontier economies.
In this section we develop a basic design for a decentralised trade finance model, aiming at answering the following general question: "how would a DeFi trade finance model look like?". In line with the modelling process summarized in Section 5.3., this section is divided into three sub-sections, each one depicting how a specific use or element of DeFi (in the broad sense hereby provided) modifies the traditional trade finance business model.

\section{The disintermediation element}

International trade can be described in general terms as three inter-dependent flows: physical flows (merchandise/commodities), information flows (EDI, XML, documents), and financial flows (letters of credit, documentary collections, advance payments, etc.). Trade finance instruments like LCs can be described, more specifically, as an inter- dependent flow of documents and money, closely dependent too on cargo flows.

Figure 1, taken from (51), depicts the traditional process flow for a documentary letter of credit.

The system works in a series of pair-based relationships: importer/exporter, importer/issuing bank, issuing bank/advising (confirming) bank, advising (confirming) bank/exporter. For each of these relationships, information (including documents) and money is exchanged. The validation and authentication of documents is done through the intermediation of the issuing bank and the advising (which can also be confirming) bank: the advising bank has to trust the issuing bank, and the exporter has to trust the advising bank, as to the authenticity of the LC.

Figure 2 shows the same documentary LC workflow, processed through a DLT platform.

DLT allows for this trust to be disintermediated and deposited in the platform itself. From the very first step of applying for an LC, the importer might use a frontend application through which relevant parameters (port of load, port of destination, sale price, etc.) are stored in the platform. Documents themselves are not to be stored, but rather their relevant parameters. This way, several of the authentication and verification functions performed by banks, which address the information asymmetry problem, are delegated (disintermediated) to the DLT platform.

\section{A Decentralised Trade Finance Model Design}

The alternative finance element

Figure 1. Documentary letter of credit traditional workflow model.

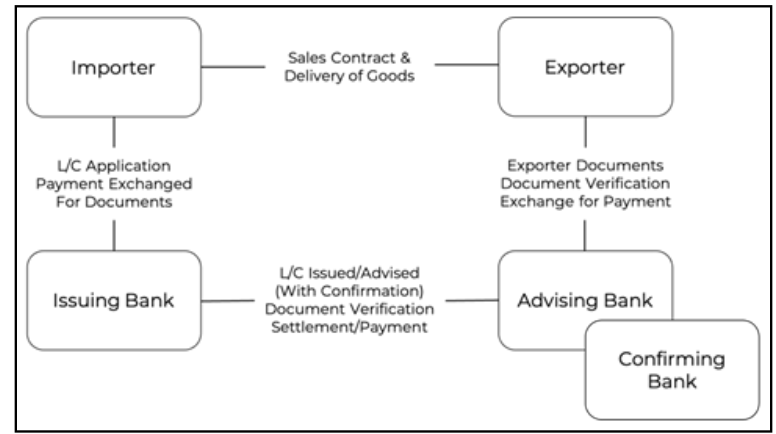


In the traditional model for LCs, the delivery vs payment (DvP) dilemma is solved by bank guaranteeing payment against a compliant presentation of documents. The system works through a forward relay of information and documents, and a backwards relay interchange of documents for money, as depicted in figure 3 (dashed lines represent information flows, dotted lines represent financial flows).

In the forward relay, the importer applies for an LC; the issuing bank transmits the LC to the advising/confirming bank, which in turn confirms the authenticity of the LC (advises it) to the exporter. Then, in the backwards relay, the exporter presents relevant documents (BL, BE, and other documents like commercial invoice, certificate of origin, etc.) to the advising/confirming bank and receives payment; the advising/confirming bank forwards the documents to the issuing bank and gets reimbursed; and the issuing bank delivers the documents to the importer against reimbursement. The exporter gets paid by the advising/confirming bank either with funds from the bank itself, or by funds obtained through the negotiation of the LC in the secondary market.

Figure 4 depicts a modified version of the system (excluding the forward relay), showing how alternative finance comes into place.
In the alternative finance system, the backwards relay interchange of documents for money works in a similar way. The novel element is provided by the tokenization of the LC, in order to expand its tradability in the secondary market. In other words, the LC becomes a digital asset with embedded intrinsic value (69), in this case represented by the right to collect principal and interest from the importer, behaving very much like a bond.

LCs can be securitized either as single units or by fractioning them in sub-units, much like mortgage-backed securities (MBS). Each unit or sub-unit would be represented, as a digital asset, by a tradable token. For most LCs, securitization will require their slicing into smaller sub-units, given that the average value of an LC is considerably high4.

The use of an alternative finance mechanism, P2P-based or not, is expected to increase liquidity for the trade finance system, as an expansion of the secondary market. One of the benefits of tokenized markets in relation to other secondary markets is the decrease of transaction costs, which in turn increases access of smaller players. Cryptocurrency digital exchanges (such as Coinbase, Binance or Kraken) have relatively simple onboarding mechanisms and very low transaction costs when compared with the costs of participating in the stock market. If the secondary market for LCs and other trade finance instruments can be to-

Figure 2. Documentary letter of credit workflow with DLT-based solution.

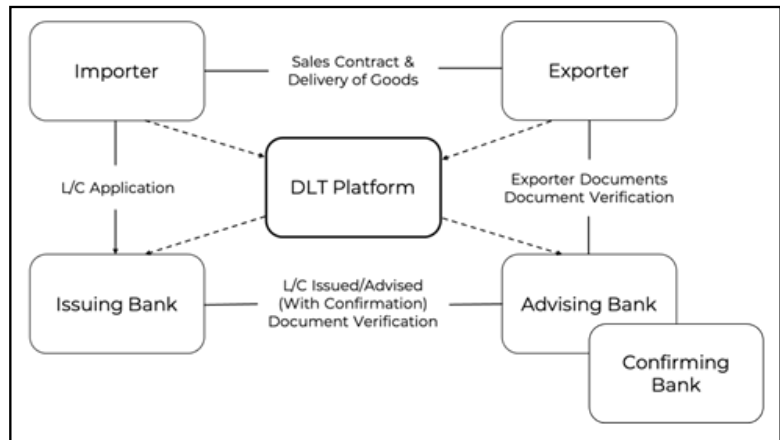

Figure 3. Forward and backwards relays in documentary letter of credit.

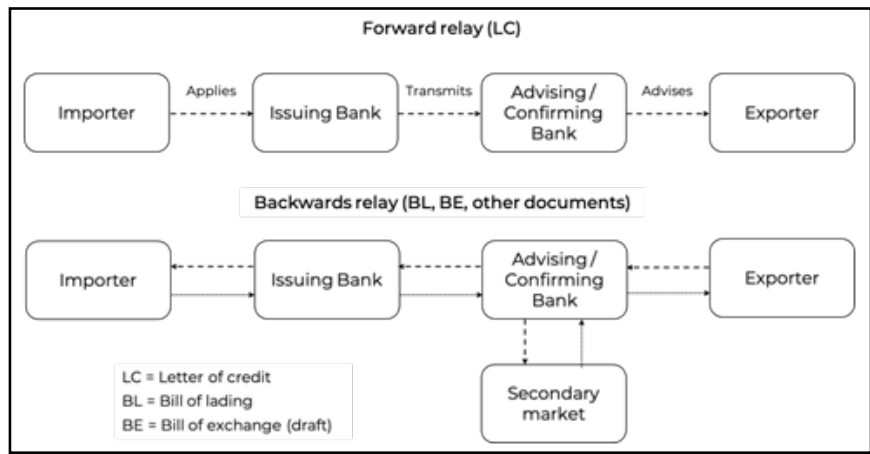

Figure 4. Alternative finance system.

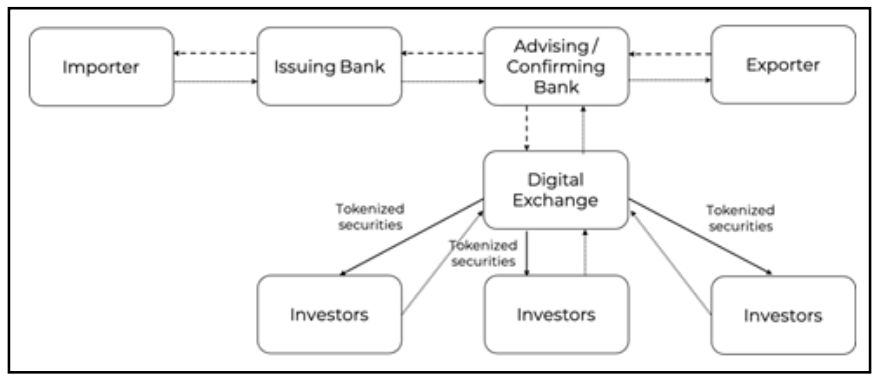


kenized, the supply of funds through additional retail investors should contribute to its expansion.

\section{The unbundling element}

As described above, the unbundling element in DeFi is manifested in the provision of financial services by separate players, who can specialize in a particular set of functions. In a traditional trade finance model, three financial functions are provided: the administrative function (collecting information and processing documents from importer, exporter and other actors), the risk management function (assessing the creditworthiness of the importer and the performance level of the exporter), and the financial sourcing function (providing funds).

Figure 5 shows a possible configuration of this unbundling, where issuing and advising/confirming banks outsource certain services to specialized entities. Document and information processing could be done by a frontend application provider. Risk management could be provided by a global bank with extensive knowledge in trade finance. And the source of capital would be digital exchanges, setting and monitoring tokenized secondary markets.

In this configuration, issuing banks retain their relationship with importers, and advising/confirming banks with exporters. But several services needed for the effective execution of the LC workflow are outsourced to more efficient entities. The fundamental role played by DLT/blockchain technology is to provide a single information infrastructure where several actors can obtain the same information inputs in order to perform their separate functions.

\section{Evaluation}

\section{Preliminary considerations}

[16] present a framework for evaluating DSR projects, composed of three maturity levels, as shown on table 2 (reproduced from their research essay).

The contribution intended by this paper is situated in Level 2 of the framework: it presents principles, in the form of elements (disintermediation, alternative finance, unbundling), for developing a DeFi trade finance business model. The artifact, at this stage, consist in the model presented in Section 5, plus the discussion about a theoretical construct (decentralised finance) contained in Section 4.

This ex-ante evaluation will cover two areas: practical assessment and theoretical contribution.

\section{Practical assessment}

The practical assessment of the artifact, represented by the business model, amounts to answering a simple question: is it useful? A question that in this case can be rendered more explicitly as: does the model addresses the problems behind the trade finance gap?

Following the classification in Section 2, the usefulness of the model in addressing supply-related problems and demand-related problems is considered in turn.

\section{Addressing supply-related problems}

The Basel III capital requirements and minimal non-bank capital investments, while having different origins (regulatory and economic), generate an important problem behind the trade finance gap: insufficient liquidity. This problem is addressed by the DeFi

Figure 5. Configuration of unbundled services for trade finance.

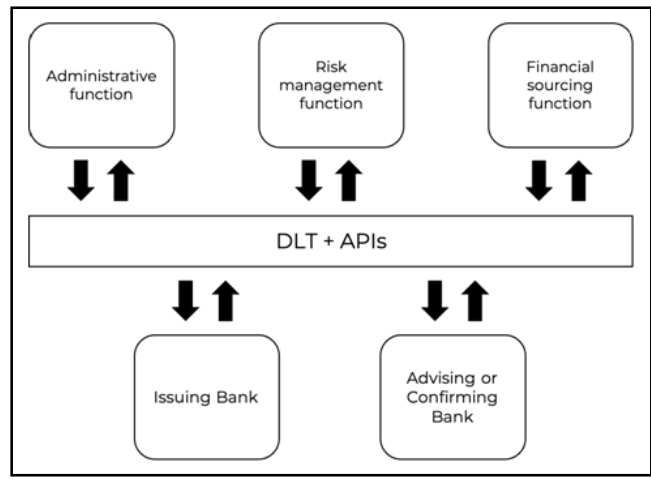

Table 2. Design Science Research Contribution Types.

\begin{tabular}{|c|c|c|}
\hline 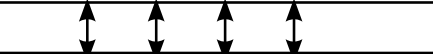 & Contribution Types & Example Artifacts \\
\hline \multirow[t]{2}{*}{$\begin{array}{l}\text { More abstract, complete and } \\
\text { mature knowledge }\end{array}$} & $\begin{array}{l}\text { Level 3. Well-developed design theory about } \\
\text { embedded phenomena }\end{array}$ & $\begin{array}{l}\text { Design theories (mid-range and } \\
\text { grand theories) }\end{array}$ \\
\hline & $\begin{array}{l}\text { Level 2. Nascent design theory-knowledge } \\
\text { as operational principles/ architecture }\end{array}$ & $\begin{array}{l}\text { Constructs, methods, models, design } \\
\text { principles, technological rules }\end{array}$ \\
\hline $\begin{array}{l}\text { More specific, limited, and less } \\
\text { mature knowledge }\end{array}$ & Level 1. Situated implementation of artifact & $\begin{array}{c}\text { Instantiations (software products or } \\
\text { implemented processes) }\end{array}$ \\
\hline
\end{tabular}


trade finance model through the alternative finance element: the development of a tokenized/securitized secondary market.

$\mathrm{KYC} / \mathrm{AML}$ requirements, being related to regulatory issues, are not addressed by the model. High-processing costs and document verification problems are closely related. The still paper-based nature of the whole process has been identified as one key reason behind high processing costs. Most document verification issues arise out of archaic procedures and tasks. The digital transformation enhanced by DLT, in particular by the immutable registration of relevant parameters in a distributed database, would significantly reduce incongruencies between documents (LCs, BLs and Bes), which are the source of many delays and additional costs.

This increased efficiency provided by DLT would cover the whole lifecycle of the LC, from its issuance to its securitization, including execution, clearing and settlement of securities, as explained by [63].

Finally, the unbundling of financial services would allow local banks who do not have sufficient knowledge about trade finance, to receive assistance from specialized providers in matters such as creditworthiness assessment and secondary market negotiation. Global banks who currently concentrate most of trade finance could provide creditworthiness assessments for LCs to be issued or confirmed by local banks in emerging and frontier markets, without taking part in the financing. This would decrease participation costs, as understood by [6].

\section{Addressing demand-related problems}

High processing costs (partially caused by inefficient document verification procedures) affect SMEs by increasing transaction costs. In turn, this high transaction costs elevate the transactionsize threshold above which is economically viable to use an LC. All these problems would be addressed by DLT-based digital transformation, as already explained.

The insufficient knowledge about trade finance by importers and exporters can similarly addressed through the unbundling principle. For instance, a specialized frontend application service could guide the importer in the process of applying for an LC, and the exporter for making a compliant presentation under UCP 600 rules.

Firm-related level of risk reflects an asymmetry of information problem. A DLT-based system would help SMEs with good track record to signal its creditworthiness more easily to banks with whom they do not have previous experience. Indeed, all the relevant information about previous LCs would be accurately and immutable registered in a distributed database. These functionalities would be particularly beneficial to countries with low levels of digitalization, which will face higher hurdles in the post-COVID-19 era.

Country-related level of risk is not addressed by the model.

Table 3 presents the problems, the way they are addressed by the model, and the corresponding DeFi element.

\section{Theoretical contribution}

The theoretical contribution aimed at by this paper is twofold. On the one hand, it discusses the theoretical construct of "decentralised finance", identifying previous usages and its current narrow meaning under the "DeFi" abbreviation, while developing a broader meaning. This is done by making explicit several elements implicit in the notion of decentralization, namely: disintermediation, decreased concentration, unbundling and alternative finance. On the other hand, the research uses these elements in order to design a business model that addresses a real-life problem, in this case, the trade finance gap. This application looks to generate prescriptive knowledge or, following the theoretical taxonomy by [37], theory for design and action.

\section{Conclusion}

This paper has addressed a practical problem, the trade finance gap extensively discussed in policy circles, by inquiring whether a solution could be found in decentralised finance (DeFi). To this end, it has presented a theoretical background, including the academic and policy treatment of the trade finance problem, including the context created by the COVID-19 pandemic, as well as literature about the concepts of financial intermediation and business model innovation. Then, it has discussed the DeFi concept, offering a broader meaning, based on specific elements. These

Table 3. Addressing trade finance gap problems with DeFi.

\begin{tabular}{|c|c|c|}
\hline Trade finance gap causes & Addressed by & DeFi element \\
\hline $\begin{array}{c}\text { Increased capital ratio requirements in banking } \\
\text { regulations (e.g.: Basel III) }\end{array}$ & $\begin{array}{c}\text { Additional capital from investors in tokenized } \\
\text { secondary market }\end{array}$ & Alternative finance \\
\hline Regulatory due diligence requirements (e.g. KYC) & Not addressed by the model & Not applicable \\
\hline Minimal non-bank capital & $\begin{array}{c}\text { Additional capital from investors in tokenized } \\
\text { secondary market }\end{array}$ & Alternative finance \\
\hline High processing costs & Digitalization of processes & Disintermediation \\
\hline Document verification problems & Digitalization of processes & Disintermediation \\
\hline $\begin{array}{c}\text { Insufficient knowledge about trade finance by } \\
\text { local banks and by importers or exporters }\end{array}$ & $\begin{array}{c}\text { Financial services provided by specialized firms } \\
\text { or global banks / Reduced participation costs }\end{array}$ & Unbundling \\
\hline Firm related high level of risk & Reduced information asymmetries & Unbundling \\
\hline Country related high level of risk & Not addressed by the model & Not applicable \\
\hline Insufficient size of transactions & Digitalization of processes & Disintermediation \\
\hline
\end{tabular}


elements in turn have been used in the design of a DeFi business model that would address the trade finance gap. Finally, a preliminary evaluation of the model and the theoretical contribution has been offered.

Several limitations are present in this paper. First and foremost, it represents a preliminary stage in the DSR process, where only a model is presented: it does not include methods or an actual instantiation. Second, all the data presented is obtained from secondary sources, also due to the early stage of the research. Also, the discussion is limited to documentary letters of credit, leaving out several other important trade finance instruments like documentary collections (DC), standby letters of credit (SLC) or factoring.

This opens opportunities for future research. A separate DeFi business model for DCs, SLCs or factoring could be designed. Also, more detailed analysis of the application of DLT to specific business processes related to trade finance can be conducted. For example, how information gathered during the origination phase of an LC and registered as relevant parameters in a DLT platform, could be useful for securitization processes in the secondary market.

\section{Declaration Of Competing Interest}

The authors declare that they have no known competing financial interests or personal relationships that could have appeared to influence the work reported in this paper.

\section{References}

[1]. ADB. Trade Finance Gaps, Growth, and Jobs Survey. 2017.

[2]. Adrian T, Shin HS. Liquidity and leverage. Journal of financial intermediation. 2010 Jul 1:19(3):418-37.

[3]. AfDB. Trade Finance in Africa: Overcoming Challenges. 2017

[4]. Ahn J, Amiti M, Weinstein DE. Trade finance and the great trade collapse. American Economic Review. 2011 May;101(3):298-302.

[5]. Allen F, Qian J, Carletti E, Valenzuela P. Financial Intermediation, Markets, and Alternative Financial Sectors. SSRN Electronic Journal. 2012.

[6]. Allen F, Santomero AM. The theory of financial intermediation. Journal of banking \& finance. 1997 Dec 1;21(11-12):1461-85.

[7]. Allen F, Santomero AM. What do financial intermediaries do?. Journal of Banking \& Finance. 2001 Feb 1;25(2):271-94

[8]. Amler H, Eckey L, Faust S, Kaiser M, Sandner P, Schlosser B. DeFi-ning DeFi: Challenges \& Pathway. arXiv preprint arXiv:2101.05589. 2021 Jan 14.

[9]. Andolfatto D, Nosal E. Money, intermediation, and banking. Journal of Monetary Economics. 2009 Apr 1;56(3):289-94.

[10]. Auboin M. Trade Finance under the Current Basel Regulatory Framework: What are the Issues. Trade Finance during the Great Trade Collapse. The World Bank, Washington, DC. 2011 Jun 22:385-92.

[11]. Auboin M. Trade finance, gaps and the covid-19 pandemic: A review of events and policy responses to date. 2021.

[12]. Auboin M, Blengini I. The Impact on Basel III on Trade Finance: The Potential Unintended Consequences of the Leverage Ratio. 2014

[13]. Auboin M, DiCaprio A. Why do trade finance gaps persist: Does it matter for trade and development?. 2017.

[14]. Aversa P, Haefliger S, Rossi A, Baden-Fuller C. From business model to business modelling: Modularity and manipulation. In Business models and modelling 2015 Oct 27;33: 151-185.

[15]. Baden-Fuller C, Morgan MS. Business models as models. Long range planning. 2010 Apr 1;43(2-3):156-71.

[16]. Beck R, Weber S, Gregory RW. Theory-generating design science research. Information Systems Frontiers. 2013 Sep 1;15(4):637-51

[17]. Behn M, Daminato C, Salleo C. A dynamic model of bank behaviour under multiple regulatory constraints. 2019

[18]. Benston GJ, Smith CW. A transactions cost approach to the theory of fi- nancial intermediation. The Journal of finance. 1976 May 1;31(2):215-31.

[19]. Berger AN, Bouwman CH, Kick T, Schaeck K. Bank liquidity creation following regulatory interventions and capital support. Journal of Financial Intermediation. 2016 Apr 1;26:115-41.

[20]. Berger SC, Gleisner F. Emergence of financial intermediaries in electronic markets: The case of online P2P lending. BuR Business Research Journal. 2009 May 11;2(1):39-65.

[21]. Berne Union. Export Credit Insurance Industry Response to the COVID-19 Pandemic. 2020

[22]. Boissay F, Patel N, Shin HS. Trade credit, trade finance, and the Covid-19 Crisis. Trade Finance, and the COVID-19 Crisis.2020 June 19.

[23]. Leland HE, Pyle DH. Informational asymmetries, financial structure, and financial intermediation. The journal of Finance. 1977 May 1;32(2):371-87.

[24]. Bruett T. Cows, kiva, and prosper. com: How disintermediation and the internet are changing microfinance. Community Development Investment Review. 2007;3(2):44-50.

[25]. Chen Y, Bellavitis C. Blockchain disruption and decentralized finance: The rise of decentralized business models. Journal of Business Venturing Insights. 2020 Jun 1;13:e00151.

[26]. Chircu AM, Kauffman RJ. Strategies for Internet middlemen in the intermediation/disintermediation/reintermediation cycle. Electronic Markets. 1999 Jan 1;9(1-2):109-17.

[27]. Chircu AM, Kauffman RJ. Reintermediation strategies in business-to-business electronic commerce. International Journal of Electronic Commerce. 2000 Jul 1;4(4):7-42.

[28]. Chircu AM, Kauffman RJ. Digital intermediation in electronic commerce. In S. Barnes \& B. Hunt (Eds.), E-Commerce and V-Business: Business Models for Global Success. Butterworth-Heinemann. 2001: 45-66.

[29]. Cong LW, He Z, Li J. Decentralized Mining in Centralized Pools. 2019.

[30]. Demir B, Javorcik B. Trade finance matters: evidence from the COVID-19 crisis. Oxford Review of Economic Policy. 2020;36:397-408.

[31]. DiCaprio A, Yao Y. Drivers of trade finance gaps. ADBI Working Paper; 2017.

[32]. Ertürk I. Financialization, bank business models and the limits of post-crisis bank regulation. Journal of banking regulation. 2016 Mar;17(1):60-72.

[33]. Frankenberger K, Weiblen T, Csik M, Gassmann O. The 4I-framework of business model innovation: A structured view on process phases and challenges. International journal of product development. 2013 Jan 1;18(34):249-73.

[34]. Gassmann O, Frankenberger K, Sauer R. Exploring the field of business model innovation: New theoretical perspectives. Springer; 2016 Oct 1.

[35]. Gelb A. Balancing Financial Integrity with Financial Inclusion: The RiskBased Approach to "Know Your Customer". CGD Policy Paper. 2016 Feb;74:1-24.

[36]. Gomber P, Kauffman RJ, Parker C, Weber BW. On the fintech revolution: Interpreting the forces of innovation, disruption, and transformation in financial services. Journal of management information systems. 2018 Jan 2;35(1):220-65.

[37]. Gregor S. The nature of theory in information systems. MIS quarterly. 2006 Sep 1:611- 42

[38]. Gregor S, Hevner AR. Positioning and presenting design science research for maximum impact. MIS quarterly. 2013 Jun 1; 37(2): 337-355.

[39]. Gudgeon L, Perez D, Harz D, Livshits B, Gervais A. The decentralized financial crisis. In 2020 Crypto Valley Conference on Blockchain Technology (CVCBT) 2020 Jun 11:1-15. IEEE.

[40]. Hayes B. If money is the root of all evil, what does that say of the banks? Medium.Com. 2018 may 27

[41]. Hevner AR, March ST, Park J, Ram S. Design Science in Information Systems Research. MIS Quarterly, 2004 Mar 1; 28(1): 251-266.

[42]. Horváth R, Seidler J, Weill L. Bank capital and liquidity creation: Granger-causality evidence. Journal of Financial Services Research. 2014 Jun;45(3):341-61.

[43]. ICC. Rethinking Trade and Finance. 2017.

[44]. ICC. Global Trade - Securing Future Growth. 2018

[45]. Khan MS, Scheule H, Wu E. Funding liquidity and bank risk taking. Journal of Banking \& Finance. 2017 Sep 1;82:203-16.

[46]. Klagge B, Martin R. Decentralized versus centralized financial systems: is there a case for local capital markets?. Journal of Economic Geography. 2005 Aug 1;5(4):387-421.

[47]. Lee I, Shin YJ. Fintech: Ecosystem, business models, investment decisions, and challenges. Business horizons. 2018 Jan 1;61(1):35-46.

[48]. Lima F, Soares de Pinho P. Financial disintermediation and the measurement of efficiency in banking: the case of Portuguese banks. International Journal of Banking, Accounting and Finance. 2008 Jan 1;1(2):133-48.

[49]. Lipton A. Block chains and distributed ledgers in retrospective and perspective. The Journal of Risk Finance. 2018: 537-560. 
[50]. Lipton A, Pentland A. Breaking the bank. Scientific American. 2018 Jan;318(1):26-31.

[51]. Malaket AR. Financing trade and international supply chains: commerce across borders, finance across frontiers. Routledge; 2016 Apr 15.

[52]. March ST, Smith GF. Design and natural science research on information technology. Decision support systems. 1995 Dec 1;15(4):251-66.

[53]. Mendicino C, Nicolov K, Suarez J, Supera D. Bank capital in the short and in the long run. 2019.

[54]. Merton RC. Financial innovation and the management and regulation of financial institutions. Journal of Banking \& Finance. 1995 Jun 1;19(34):461-81.

[55]. Nellis JG, McCaffery KM, Hutchinson RW. Strategic challenges for the European banking industry in the new millennium. International Journal of Bank Marketing. 2000 Apr 1;18(2): 53-64.

[56]. Niepmann F, Schmidt-Eisenlohr T. International Trade, Risks, and the Role of Banks. 2014.

[57]. Niepmann F, Schmidt-Eisenlohr T. International trade, risk and the role of banks. Journal of International Economics. 2017 Jul 1;107:111-26.

[58]. Nyantakyi EB, Drammeh LM. COVID-19 PANDEMIC: Potential Risks for Trade and Trade Finance in Africa. Africa Economic Brief. 2020; 11(6).

[59]. Oates WE. Federalism and Government Finance. In J. M. Quigley \& E. Smolensky (Eds.), Modern Public Finance. Harvard University Press. 1994:126-151.

[60]. OECD. Trade Finance in the COVID era: Current and future challenges. 2021.

[61]. Shome D, Pati AP. Disintermediation in financial services: an empirical investigation of Indian banking sector. Indian journal of commerce. 2006 Jul;59(3): 153-163.

[62]. Pflaum I, Hateley E. A Bit of a Problem: National and Extraterritorial Regulation of Virtual Currency in the Age of Financial Disintermediation. Georgetown Journal of International Law, 2014;45(4): 1169-1215.

[63]. Pinna A, Ruttenberg W. Distributed ledger technologies in securities posttrading: Revolution or evolution?. 2016 Apr 26; 172.

[64]. Sansa NA. The Impact of the COVID-19 on the Financial Markets: Evidence from China and USA. Electronic Research Journal of Social Sciences and Humanities. 2020 Apr 3; 2(2): 29-39.

[65]. Schär F. Decentralized finance: On blockchain-and smart contract-based financial markets. FRB of St. Louis Review. 2021 Apr; 103(2): 153-174.

[66]. Schmid V. Bank Money: The Root of All Evil. The Epoch Times. 2019 January 10 .

[67]. Sonnenberg C, Vom Brocke J. Evaluations in the science of the artificial-reconsidering the build-evaluate pattern in design science research. InInternational Conference on Design Science Research in Information Systems. 2012 May 14;381-397. Springer, Berlin, Heidelberg.

[68]. Stiglitz JE, Weiss A. Credit rationing in markets with imperfect information. The American economic review. 1981 Jun 1;71(3):393-410.

[69]. Tasca P. Token-based business models. In Disrupting finance. Palgrave MacMillan. 2019: 135-148.

[70]. Tasca P, Vigliotti MG, Gong H. Risks and challenges of initial coin offerings. Journal of Digital Banking. 2018 Aug 1;3(1):81-96.

[71]. Venable J, Pries-Heje J, Baskerville R. FEDS: a framework for evaluation in design science research. European journal of information systems. 2016 Jan;25(1):77-89.

[72]. Vidya CT, Prabheesh KP. Implications of COVID-19 pandemic on the global trade networks. Emerging Markets Finance and Trade. 2020 Aug $8 ; 56(10): 2408-21$

[73]. Walker GA. (2011). Basel III market and regulatory compromise. Journal of Banking Regulation. 2011; 12(2): 95-99.

[74]. WEF. Trade Tech - A New Age for Trade and Supply Chain Finance.2018.

[75]. WEF.Mapping Trade Tech: Trade in the Fourth Industrial Revolution. 2020.

[76]. Wibbels E, Rodden J. Business cycles and the political economy of decentralized finance: lessons for fiscal federalism in the EU. P. Wierts et al., Fiscal Policy Surveillance in Europe, Macmillan. 2006: 161-183.

[77]. WTO. Trade Finance and SMEs: Bridging the gaps in provision.2016.

[78]. Zetzsche DA, Arner DW, Buckley RP. Decentralized finance. Journal of Financial Regulation. 2020 Sep 20;6(2):172-203.

[79]. Zott C, Amit R. Business model design and the performance of entrepreneurial firms. Organization science. 2007 Apr;18(2):181-99.

[80]. Zott C, Amit R. Business model design: An activity system perspective. Long range planning. 2010 Apr 1;43(2-3):216-26. 